\title{
Expression of the Hepatocellular Chloride-dependent Sulfobromophthalein Uptake System in Xenopus laevis Oocytes
}

Emmanuel Jacquemin, Bruno Hagenbuch, Bruno Stieger, Allan W. Wolkoff, ${ }^{\star}$ and Peter J. Meier

Division of Clinical Pharmacology, Department of Medicine, University Hospital, CH-8091 Zurich/Switzerland; and *Department of Medicine and the Marion Bessin Liver Research Center, Albert Einstein College of Medicine, Bronx, New York 10461

\section{Abstract}

The expression of the basolateral chloride-activated organic anion uptake system of rat hepatocytes has been studied in Xenopus laevis oocytes. Injection of oocytes with rat liver poly $(A)^{+}$RNA resulted in the functional expression of chloridedependent sulfobromophthalein (BSP) uptake within 3-5 d. This expressed chloride-dependent BSP uptake system exhibited saturation kinetics (apparent $K_{m} \sim 6.2 \mu \mathrm{M}$ ) and efficiently extracted BSP from its binding sites on BSA. Furthermore, the chloride-activated portion of BSP uptake was inhibited by bilirubin (10 $\mu \mathrm{M}$; inhibition 53\%), 4,4'-diisothiocyano-2,2-disulfonic acid stilbene (DIDS, $100 \mu \mathrm{M} ; 80 \%)$, taurocholate (100 $\mu \mathrm{M} ; 80 \%)$, and cholate $(200 \mu \mathrm{M} ; 95 \%)$. In contrast to results with total rat liver $m R N A$, injection of $m R N A$ derived from the $\mathrm{Na}^{+}$/bile acid cotransporter cDNA (Hagenbuch, B., B. Stieger, M. Foguet, H. Lübbert, and P. J. Meier. 1991. Proc. Natl. Acad. Sci. USA. In press.) had no effect on BSP uptake into oocytes. Size fractionation of total rat liver mRNA revealed that a 2.0- to 3.5-kb size-class mRNA was sufficient to express the hepatic chloride-dependent BSP uptake system. These data indicate that "expression cloning" in oocytes represents a promising approach to ultimately clone the cDNA coding for the hepatocyte high affinity, chloride-dependent organic anion uptake system. Furthermore, the results confirm that the $\mathrm{Na}^{+} /$ bile acid cotransport system does not mediate BSP uptake. (J. Clin. Invest. 1991. 88:2146-2149.) Key words: expressioncloning $\cdot$ hepatic organic anion uptake

\section{Introduction}

Hepatocellular uptake of the organic anions bilirubin and sulfobromophthalein (BSP) ${ }^{1}$ is generally assumed to be a carriermediated membrane transport process $(1,2)$. However, despite numerous efforts in recent years, neither the exact driving force(s) nor the putative transport protein(s) have been well defined. For example, evidence has been provided for both electrogenic $(2,3)$ and electroneutral (4) BSP uptake into hepatocytes. Furthermore, intracellular (or intravesicular) acidic (2)

Preliminary reports of this work have been accepted for presentation at the annual meeting of the American Association for the Study of Liver Diseases, Chicago, IL, November 1991, and will appear in abstract form in Hepatology.

Address correspondence to Peter J. Meier-Abt, M.D., Division of Clinical Pharmacology, Department of Medicine, University Hospital, Ch-8091, Zurich, Switzerland. 1991.

Received for publication 16 July 1991 and in revised form 29 August

1. Abbreviation used in this paper: BSP, sulfobromophthalein.

J. Clin. Invest.

(c) The American Society for Clinical Investigation, Inc.

$0021-9738 / 91 / 12 / 2142 / 04 \$ 2.00$

Volume 88, December 1991, 2146-2149 as well as alkaline (4) $\mathrm{pH}$ gradients have been proposed to drive hepatocytic BSP uptake. And finally, several distinct proteins have been identified as candidate BSP transporters, including the so called BSP/bilirubin binding protein $(\sim 55 \mathrm{kD})(1)$, the organic anion binding protein $(\sim 55 \mathrm{kD})(5,6)$, and the bilitranslocase $(\sim 37 \mathrm{kD})(2)$. Although all these proteins have been suggested as having a role in BSP uptake, none have been characterized fully on the molecular level nor has their structure/function relationship(s) been established.

As recently demonstrated, a characteristic feature of hepatocellular BSP uptake is its dependence on extracellular chloride $(3,4,7)$. In cultured rat hepatocytes this chloride-dependent uptake system has an exceptionally high affinity for BSP $\left(K_{\mathrm{m}} \sim 0.3 \mu \mathrm{M}\right)$, resulting in efficient extraction of BSP from its binding sites on albumin $(4,7)$. Because none of the putative BSP-transporting polypeptides (see above) has been identified as mediating chloride-dependent BSP uptake, we adopted a functional expression cloning strategy to isolate and characterize the full length cDNA encoding this important hepatocytic transport system. In this study we report the successful expression of chloride-dependent BSP uptake in Xenopus laevis oocytes injected with either total rat liver mRNA or a $2.0-3.5-\mathrm{kb}$ size-class thereof. Furthermore, the results demonstrate that the recently cloned hepatocellular $\mathrm{Na}^{+} /$bile acid cotransporter (8) does not mediate BSP uptake, thus confirming the involvement of different transport systems in the hepatocyte uptake of bile acids and of non-bile acid organic anions $(1,2)$. Hence, expression cloning represents a promising approach to ultimately characterize the gene of the basolateral chloride-dependent BSP uptake system of rat liver.

\section{Methods}

Materials. ${ }^{35} \mathrm{~S}$-labeled BSP was prepared at a specific activity of $4 \mathrm{Ci} /$ mmol by sulfonation of phenoltetrabromophthalein with $\mathrm{H}_{2}^{35} \mathrm{SO}_{4}$ as described (9). [6- $\left.{ }^{3} \mathrm{H}\right]$ Taurocholic acid $(2.1-6.6 \mathrm{Ci} / \mathrm{mmol})$ and $[2,4-$ ${ }^{3} \mathrm{H}$ ]cholic acid $(25 \mathrm{Ci} / \mathrm{mmol})$ were obtained from Du Pont-New England Nuclear (Boston, MA). Guanidinium isothiocyanate, phenol, and sucrose were from Bethesda Research Laboratories (Gaithersburg, MD). Oligo (dT)-cellulose (type 7) was obtained from Pharmacia LKB Biotechnology Inc. (Piscataway, NJ). Ethyl m-aminobenzoate (MS222) was purchased from Sandoz Ltd. (Basel, Switzerland).

Animals. Male Sprague-Dawley rats (SUT:SDT) weighing 200-250 $\mathrm{g}$ were obtained from the Süddeutsches Tierzuchtinstitut (Tuttlingen, Germany) and fed ad lib. until used. Mature $X$. laevis females were purchased from $H$. Kähler (Hamburg, Germany) and kept under standard conditions as described (10).

Isolation of rat liver $m R N A$. Total RNA from $10 \mathrm{~g}$ of rat liver was prepared and mRNA purified, size-fractionated, and precipitated as previously described (11). Isolated mRNA was resuspended in water and stored at $-80^{\circ} \mathrm{C}$. mRNA concentrations were estimated by measuring the absorption at $260 \mathrm{~nm}$ (12).

Expression of $m R N A$ in Xenopus oocytes. Frogs were anesthetized by immersion for $15 \mathrm{~min}$ in a $0.1 \%$ solution of ethyl $\mathrm{m}$-aminobenzoate (MS-222). Oocytes were removed and incubated at room temperature for $2 \mathrm{~h}$ in $\mathrm{Ca}^{++}$-free OR-2 solution (10), supplemented with $2 \mathrm{mg} / \mathrm{ml}$ 
collagenase (type D; Boehringer Mannheim Biochemicals, Indianapolis, IN). They were then washed in a modified Barth's solution ( $88 \mathrm{mM}$ $\mathrm{NaCl}, 1 \mathrm{mM} \mathrm{KCl}, 2.4 \mathrm{mM} \mathrm{NaHCO}{ }_{3}, 15 \mathrm{mM}$ Hepes-NaOH, pH 7.6, $0.3 \mathrm{mM} \mathrm{Ca}\left(\mathrm{NO}_{3}\right)_{2}, 0.41 \mathrm{mM} \mathrm{CaCl}_{2}, 0.82 \mathrm{mM} \mathrm{MgSO}_{4}, 10 \mathrm{U} / \mathrm{ml}$ penicillin, $10 \mu \mathrm{g} / \mathrm{ml}$ streptomycin), supplemented with gentamycin $(50 \mu \mathrm{g} /$ $\mathrm{ml})$ and soybean trypsin inhibitor $(50 \mu \mathrm{g} / \mathrm{ml})$. After an overnight incubation at $18^{\circ} \mathrm{C}$ in modified Barth's solution, healthy oocytes were injected either with $50 \mathrm{ng}$ of rat liver $\mathrm{mRNA}(1 \mathrm{mg} / \mathrm{ml})$ or with $0.5 \mathrm{ng}$ of mRNA derived from the recently characterized "prLNaBA" cDNA clone encoding the hepatocyte $\mathrm{Na}^{+}$/bile acid cotransport system (8). Control oocytes were either treated with corresponding volumes of $\mathrm{H}_{2} \mathrm{O}$ or not injected at all. Subsequently, oocytes were cultured for 3-5 $\mathrm{d}$ at $18^{\circ} \mathrm{C}$ with a daily change of modified Barth's solution.

BSP uptake into oocytes. Cultured oocytes were washed twice at $25^{\circ} \mathrm{C}$ in chloride-containing or chloride-free uptake media consisting of either (in mM) $100 \mathrm{NaCl}$ (or 100 choline chloride), $1.2 \mathrm{MgCl}_{2}, 0.81$ $\mathrm{MgSO}_{4}, 2.5 \mathrm{CaCl}_{2}, 25$ Hepes-Tris, $\mathrm{pH} 7.2$, or 100 sodium gluconate (or 200 sucrose), $1.2 \mathrm{Mg}$ (gluconate) $)_{2}, 0.81 \mathrm{MgSO}_{4}, 2.5 \mathrm{Ca}$ (gluconate) $)_{2}, 25$ Hepes-Tris, $\mathrm{pH} 7.2$, respectively. Between 7 and 10 oocytes were then incubated at $25^{\circ} \mathrm{C}$ in $100 \mu \mathrm{l}$ of the corresponding uptake medium supplemented with $1-2 \mu \mathrm{Ci}$ of $\left.{ }^{35} \mathrm{~S}\right] \mathrm{BSP}$ and $7.35 \times 10^{-3} \mathrm{mM}(0.05 \%) \mathrm{BSA}$. With the exception of the kinetic uptake studies, the concentrations of BSP in the uptake media were adjusted to 2 or $4 \mu \mathrm{M}$ and the albumin/ BSP ratios kept constant at 3.7:1 (7). After the indicated time interval, the uptake was stopped by the addition of $1 \mathrm{ml}$ of ice-cold stop solution which was similar in composition to the $\mathrm{NaCl}$ uptake buffer except that $0.74 \mathrm{mM}(5 \%)$ BSA was included in order to reduce nonspecific surface binding of tracer BSP. Furthermore, oocytes were additionally washed $3 \times$ with $8 \mathrm{ml}$ of cold stop solution. Single oocytes were then dissolved in $500 \mu \mathrm{l}$ of $10 \%$ (wt/wt) SDS. After addition of $5 \mathrm{ml}$ of scintillation fluid (Opti-Fluor ${ }^{\mathrm{TM}}$; Packard Instrument International S.A., Zurich, Switzerland) the oocyte-associated radioactivity was determined in a Packard Tri-Carb ${ }^{\mathrm{TM}} 2200$ CA liquid scintillation analyzer.

Taurocholate uptake into oocytes. The overall transport competence of mRNA-injected oocytes was routinely tested by parallel measurements of $\mathrm{Na}^{+}$-dependent taurocholate uptake as previously described (11). Only mRNA samples expressing satisfactory $\mathrm{Na}^{+}$-dependent taurocholate uptake were used for BSP uptake studies. In addition, oocytes injected with mRNA derived from the so-called prLNaBA cDNA clone (8) were used to examine a possible direct role of the hepatic $\mathrm{Na}^{+} /$bile acid cotransporter in BSP uptake.

Statistical analysis of data. All results are expressed as means \pm SD. Statistical significance was calculated by the unpaired Student's $t$ test.

\section{Results and Discussion}

In order to exclude mere activation of an endogenous transport system, it was first important to exclude the presence of chlo-

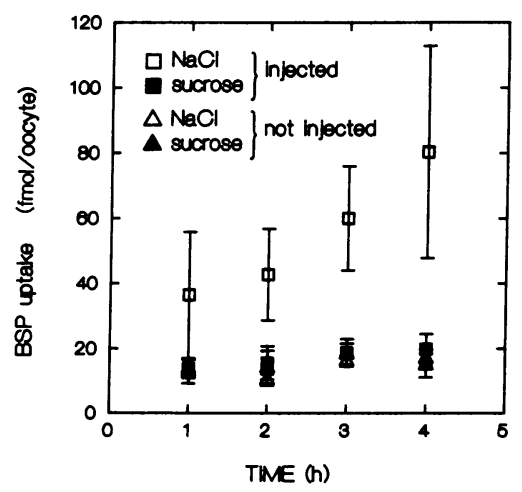

Figure 1. Expression of BSP uptake in oocytes injected with total rat liver mRNA. Oocytes were either untreated (not injected) or injected with $50 \mathrm{ng}$ of liver mRNA (injection volume: $50 \mathrm{nl}$ ). After $5 \mathrm{~d}$ of culturing at $18^{\circ} \mathrm{C}$, the oocytes were washed twice in $\mathrm{NaCl}$ or sucrose medium and uptake of $\left.{ }^{35} \mathrm{~S}\right] \mathrm{BSP}(2 \mu \mathrm{M})$ was determined at $25^{\circ} \mathrm{C}$ in the presence $(\square, \Delta)$ or absence $(\square, \Delta)$ of extracellular $\mathrm{NaCl}$, respectively. The illustrated uptake values represent the mean \pm SD of 10-20 measurements in two separate oocyte preparations.

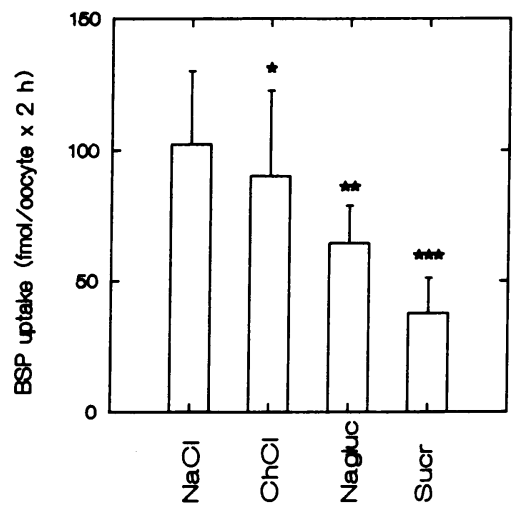

Figure 2. Effects of extracellular ion substitutions on BSP uptake into mRNA injected oocytes. Oocytes were injected with $50 \mathrm{ng}$ of total rat liver mRNA (injection volume: 50 nl). After $5 \mathrm{~d}$ of culturing at $18^{\circ} \mathrm{C}$, uptake of $\left.{ }^{35} \mathrm{~S}\right] \mathrm{BSP}(4 \mu \mathrm{M})$ was determined at $25^{\circ} \mathrm{C}$ for $2 \mathrm{~h}$ in the presence of outside $\mathrm{NaCl}$, choline chloride, sodium gluconate (each at a concen-

tration of $100 \mathrm{mM})$ or sucrose $(200 \mathrm{mM})$. The illustrated uptake values represent the mean \pm SD of 17-19 determinations in two separate oocyte preparations. ${ }^{*}$ Not significant vs $\mathrm{NaCl} ;{ }^{* *}$, significantly different from $\mathrm{NaCl}(P<0.001)$ and choline chloride $(P<0.01)$; ${ }^{* * *}$, significantly different from $\mathrm{NaCl}(P<0.001)$, choline chloride $(P<0.001)$, and sodium gluconate $(P<0.01)$.

ride-dependent BSP uptake in untreated oocytes. As demonstrated in Fig. 1, uninjected oocytes exhibited only low BSP uptake. Similar low BSP uptake was also found in water-injected oocytes (data not shown). Furthermore, no increased BSP uptake was observed in oocytes injected with total rat liver mRNA if only sucrose was present in the extracellular medium. However, in the presence of outside $\mathrm{NaCl}(100 \mathrm{mM})$ the mRNA-injected oocytes exhibited three- to sixfold higher BSP uptake as compared to results in the presence of outside sucrose or uninjected oocytes (Fig. 1). In addition, extraction of BSP from albumin was highest in the presence of chloride in the medium and was significantly reduced with gluconate substitution (Fig. 2). These BSP uptake characteristics are identical to the ones previously described in the isolated perfused rat liver (7), in cultured rat hepatocytes $(4,7)$, and in isolated rat liver sinusoidal vesicles (3). These results indicate de novo expression of this hepatocyte chloride-dependent organic anion transport system in 5-d cultured oocytes.

We next characterized the kinetics of the expressed BSP

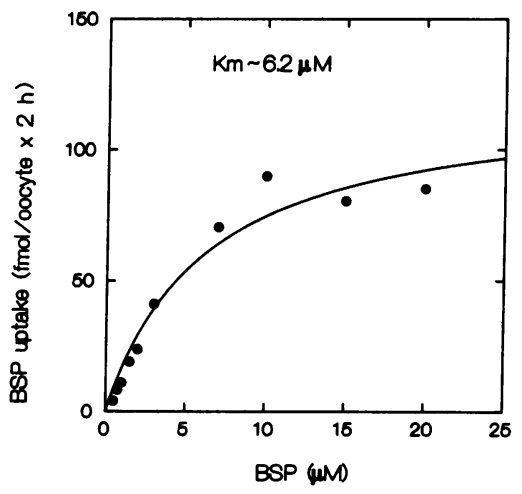

Figure 3. Kinetics of BSP uptake in mRNA injected oocytes. Oocytes were injected with $50 \mathrm{ng}$ of rat liver mRNA and cultured for $3 \mathrm{~d}$ at $18^{\circ} \mathrm{C}$. 2-h BSP uptake measurements $\left(25^{\circ} \mathrm{C}\right)$ were then performed in the presence of increasing substrate concentrations $(0.5-20$ $\mu \mathrm{M})$ in the presence of $100 \mathrm{mM} \mathrm{NaCl}$ or 200 $\mathrm{mM}$ sucrose in the incubation medium. The ratio of albumin/BSP was kept constant at 18.4:1 to minimize changes in the fraction of unbound ligand (7). The individual data points represent the difference between uptake values obtained in the presence and absence of outside $\mathrm{NaCl}$. Data represent the means of 10-20 determinations in two separate oocyte preparations. The curve was fitted by a computer-based nonlinear regression analysis. 
Table I. Effects of Various Organic Anions on Chloride-dependent BSP Uptake in mRNA-injected Oocytes

\begin{tabular}{lcr}
\hline & \multicolumn{1}{c}{ BSP uptake } \\
\hline & fmol/oocyte $\times 2 h$ & $\%$ \\
Controls & $64.5 \pm 28.3$ & 100 \\
Probenecide $(1 \mathrm{mM})$ & $41.8 \pm 11.1(\mathrm{NS})$ & 65 \\
Bilirubin $(0.01 \mathrm{mM})$ & $30.5 \pm 8.6(P<0.01)$ & 47 \\
DIDS $(0.1 \mathrm{mM})$ & $19.0 \pm 28.1(P<0.01)$ & 29 \\
Indocyanine green $(0.1 \mathrm{mM})$ & $12.6 \pm 6.4(P<0.001)$ & 20 \\
Taurocholate $(0.1 \mathrm{mM})$ & $12.6 \pm 6.4(P<0.001)$ & 20 \\
Cholate $(0.2 \mathrm{mM})$ & $3.5 \pm 3.7(P<0.001)$ & 5 \\
& &
\end{tabular}

Oocytes were injected with $50 \mathrm{ng}$ of total rat liver mRNA. After $3 \mathrm{~d}$ in culture $\left(18^{\circ} \mathrm{C}\right)$, chloride-dependent portions of BSP $(4 \mu \mathrm{M})$ uptake were determined at $25^{\circ} \mathrm{C}$ for $2 \mathrm{~h}$ in the absence (controls) and presence of the indicated concentrations of the various compounds. The absolute values are given as means \pm SD of 7-10 uptake measurements in one representative oocyte preparation. Levels of significance are given in parentheses. NS, not significant.

uptake system. As demonstrated in Fig. 3, if BSP uptake values $(2 \mathrm{~h})$ in the absence of outside chloride (isoosmotic substitution of $\mathrm{NaCl}$ with sucrose) were subtracted from uptake values in the presence of extracellular chloride $(100 \mathrm{mM} \mathrm{NaCl})$, the chloride-dependent BSP uptake portion exhibited clearcut saturability with increasing substrate concentration. Furthermore, at all substrate concentrations, BSP was efficiently extracted from albumin, because the BSP/albumin concentration ratio (1:18.4) was kept constant throughout the experiment. These results are compatible with carrier-mediated uptake of BSP into oocytes and further support the conclusion of successful expression of the hepatocytic chloride-dependent organic anion uptake system.

However, as also indicated in Fig. 3, the analysis of the saturation kinetics of the expressed chloride-dependent BSP uptake system revealed an apparent $K_{\mathrm{m}}$ value of $6.2 \mu \mathrm{M}$. While this value is consistent with various "albumin-free" BSP uptake studies in isolated rat hepatocytes (range of reported $K_{\mathrm{m}}$ values: $6.2-9.0 \mu \mathrm{M})(13-15)$ and in cultured Hep $\mathrm{G} 2$ cells $\left(K_{\mathrm{m}}\right.$ $\sim 12 \mu \mathrm{M})(16)$, it is $\sim 20-30$-fold higher than the value found for the chloride-dependent BSP uptake system in short-term cultured rat hepatocytes $\left(K_{\mathrm{m}} \sim 0.3 \mu \mathrm{M}\right)(4,7)$. The reason for this considerably lower BSP affinity of the chloride-dependent BSP uptake system in oocytes as compared to cultured hepatocytes is unknown at present, but there are several potential explanations. These include differences in the physicochemical properties between rat and Xenopus oocyte plasma membranes, and/or the inability to determine BSP uptake at substrate concentrations below $0.5 \mu \mathrm{M}$ because of low signal/noise ratios $(<1 \mu \mathrm{M})$. This situation could not be improved by increasing the incubation temperature from $25^{\circ} \mathrm{C}$ to $37^{\circ} \mathrm{C}$, because, in our hands, the oocytes did not tolerate such a high temperature for longer than $60 \mathrm{~min}$ (data not shown). Hence, as the expressed BSP uptake system was still able to efficiently extract BSP from albumin $\left(K_{\mathrm{a}}\right.$ of BSA for BSP $\sim 0.33 \mu \mathrm{M}^{-1}$; reference 4), the apparently lower BSP affinity in mRNA-injected oocytes does not invalidate the conclusion of successful expression of the hepatocyte chloride-dependent BSP uptake system. More accurate kinetic transport studies will become possible once a specific cDNA clone has been isolated. This should permit BSP uptake to be determined at lower substrate concentrations because of considerably higher transport rates $(8)$.

The current paradigm holds that BSP and bilirubin are taken up into hepatocytes by the same membrane transport system $(1,2,7,17,18)$. Therefore, bilirubin should strongly inhibit BSP uptake via the expressed transport system. In fact, as indicated in Table $\mathrm{I}, 10 \mu \mathrm{M}$ bilirubin exerted a cis-inhibitory effect of $53 \%$, which is in close agreement with the reported $K_{\mathrm{i}}$ value of $6.7 \mu \mathrm{M}$ in cultured hepatocytes (7). Furthermore, even stronger cis-inhibitions were found with the anion transport inhibitor DIDS (4,4'-diisothiocyano-2,2'stilbene disulfonate), indocyanine green, and also with relatively high concentrations of the bile acids taurocholate and cholate (Table I). Although some previous studies have suggested competition between hepatocellular uptake of bile acids and $\operatorname{BSP}(15,19)$, most studies agree that physiologic concentrations of bile acids and nonbile acid organic anions such as BSP are taken up into hepatocytes by different transport systems (for reviews see 1, 2, 18). Therefore, we also investigated whether the recently cloned $\mathrm{Na}^{+} / \mathrm{bile}$ acid cotransporter (8) could indeed mediate BSP uptake. As demonstrated in Table II, while $\mathrm{Na}^{+}$-dependent uptake of tau-

Table II. Effects of mRNA Derived from the $N a^{+} /$Bile Acid Cotransporter cDNA (prLNaBA) on Taurocholate, Cholate, and BSP Uptake in X. laevis Oocytes

\begin{tabular}{|c|c|c|c|c|}
\hline Oocyte treatment & Medium & Taurocholate $(17 \mu \mathrm{M})$ & Cholate $(0.5 \mu \mathrm{M})$ & $\operatorname{BSP}(2 \mu \mathrm{M})$ \\
\hline & & & & $\begin{array}{c}\text { fmol/oocyte } \\
\times 2 h\end{array}$ \\
\hline \multirow[t]{3}{*}{ Not injected } & $\mathrm{NaCl}$ & $90 \pm 13$ & $24 \pm 1$ & $12 \pm 4$ \\
\hline & Choline chloride & $104 \pm 24$ & $13 \pm 2$ & ND \\
\hline & Sucrose & ND & ND & $11 \pm 2$ \\
\hline Total mRNA & $\mathrm{NaCl}$ & $300 \pm 80$ & ND & $55 \pm 20$ \\
\hline \multirow[t]{2}{*}{$(25-50 \mathrm{ng})$} & Choline chloride & $146 \pm 57$ & ND & ND \\
\hline & Sucrose & ND & ND & $12 \pm 3$ \\
\hline prLNaBA-mRNA & $\mathrm{NaCl}$ & $3044 \pm 1155^{*}$ & $223 \pm 47 \ddagger$ & $15 \pm 5^{*}$ \\
\hline \multirow[t]{2}{*}{$(0.5-5 \mathrm{ng})$} & Choline chloride & $140 \pm 52^{*}$ & $16 \pm 1 \ddagger$ & ND \\
\hline & Sucrose & ND & ND & $10 \pm 2^{*}$ \\
\hline
\end{tabular}

Oocytes were either not treated or injected with total rat liver mRNA or prLNaBA-cDNA-derived mRNA. *0.5 ng; $¥ 5$ ng. Oocytes were cultured for $3 \mathrm{~d}$ and uptake of the various compounds determined as described in Methods. The values represent the means \pm SD of 10-20 determinations. $\mathrm{ND}$, not determined. 


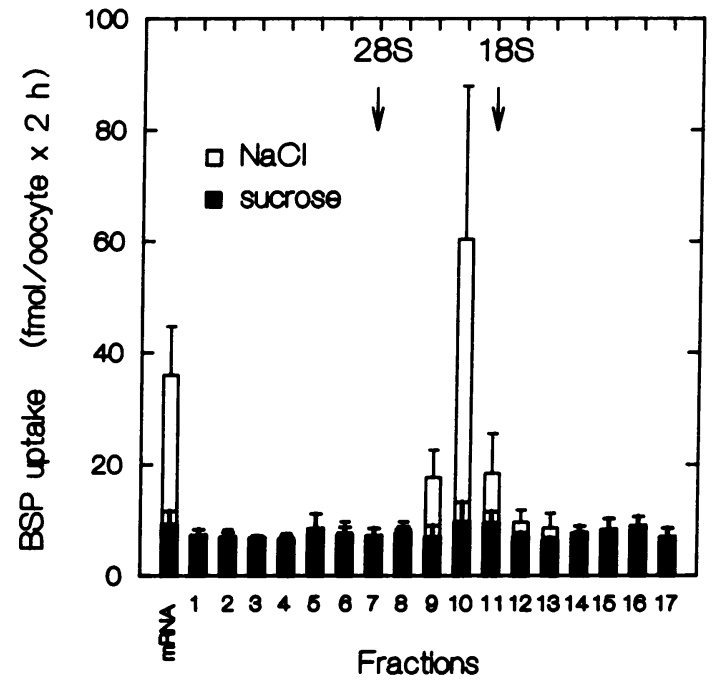

Figure 4. Fractionation of the mRNA on a linear sucrose density gradient. $150 \mu \mathrm{g}$ of total rat liver mRNA was size-fractionated on a linear (6-20\% [wt/wt]) sucrose gradient. After centrifugation $17 \times 1$ $\mathrm{ml}$ fractions were collected and the mRNA from each fraction was precipitated, washed, and resuspended in $\mathrm{H}_{2} \mathrm{O}$. 25-ng RNA samples $(50 \mathrm{nl})$ were injected into oocytes. After $3 \mathrm{~d}$ in culture the oocytes were used for BSP $(2 \mu \mathrm{M})$ uptake measurements ( $2 \mathrm{~h}$ values) in the presence of either $100 \mathrm{mM} \mathrm{NaCl}(\square)$ or $200 \mathrm{mM}$ sucrose (a) in the outside medium. The uptake values represent the mean \pm SD of 7-10 determinations in two separate oocyte preparations.

rocholate and cholate were increased 22- and 14-fold, respectively, injection of mRNA derived from the $\mathrm{Na}^{+} / \mathrm{bile}$ acid cotransporter cDNA had no effect on BSP uptake into oocytes. In contrast, chloride-dependent BSP uptake was stimulated approximately fivefold after injection of total rat liver mRNA into oocytes. These data first demonstrate that, similar to intact rat hepatocytes (20) and isolated basolateral rat liver plasma membrane vesicles (21), the cloned bile acid uptake system (8) also mediates $\mathrm{Na}^{+}$-dependent uptake of the unconjugated bile acid cholate in addition to its taurine-conjugated analogue taurocholate. Furthermore, the results confirm the concept that chloride-dependent BSP uptake occurs independent of $\mathrm{Na}^{+}$dependent bile acid uptake in rat hepatocytes. However, these studies do not exclude the possibility that $\mathrm{Na}^{+}$-independent portion of hepatocellular bile acid uptake (22) might, at least in part, also occur via the chloride-dependent BSP uptake pathway.

Finally, total rat liver mRNA was size-fractionated on a linear sucrose gradient in order to enrich the mRNA species encoding the chloride-dependent BSP uptake system. As shown in Fig. 4, the most active mRNA was found within one subfraction, which, based on additional agarose gel electrophoresis (data not shown), corresponded to a mRNA size-class between 2 and $3.5 \mathrm{~kb}$. This active mRNA subfraction is now being used to construct and screen a cDNA library in order to isolate and characterize a full-length cDNA encoding the hepatocellular chloride-dependent BSP uptake system. Hence, "expression cloning" in oocytes should ultimately provide a definite answer about the molecular structure and function of the chloride-activated hepatocellular nonbile acid organic anion uptake system.

\section{Acknowledgments}

This work was supported by Swiss National Science Foundation grants 3.992.0.87 and 32-29878.90, the Hartmann-Müller Foundation for Medical Research, University of Zurich, Switzerland, and National Institutes of Health grants DK 23026 and DK 41296. Dr. Jacquemin is a recipient of postdoctoral research fellowship awards from the Institut National de la Santé et de la Recherche Médicale (Paris) and the Fondation de France (Paris).

\section{References}

1. Berk, P. D., B. J. Potter, and W. Stremmel. 1987. Role of plasma membrane ligand-binding proteins in the hepatocellular uptake of albumin-bound organic anions. Hepatology. 7:165-176.

2. Tiribelli, C., G. C. Lunazzi, and G. L. Sottocasa. 1990. Biochemical and molecular aspects of the hepatic uptake of organic anions. Biochim. Biophys. Acta. 1031:261-275.

3. Potter, B. J., B. F. Blades, M. D. Shepard, S. M. Thung, and P. D. Berk. 1987. The kinetics of sulfobromophthalein uptake by rat liver sinusoidal vesicles. Biochim. Biophys. Acta. 898:159-171.

4. Min, A. D., K. L. Johansen, C. G. Campbell, and A. W. Wolkoff. 1991. Role of chloride and intracellular $\mathrm{pH}$ on the activity of the rat hepatocyte organic anion transporter. J. Clin. Invest. 87:1496-1502.

5. Wolkoff, A. W., and C. T. Chung. 1980. Identification, purification, and partial characterization of an organic anion binding protein from rat liver cell plasma membrane. J. Clin. Invest. 65:1152-1161.

6. Goeser, T., R. Nakata, L. F. Braly, A. Sosiak, C. G. Campbell, R. Dermietzel, P. M. Novikoff, R. J. Stockert, R. D. Burk, and A. W. Wolkoff. 1990. The rat hepatocyte membrane organic anion binding protein is immunologically related to the mitochondrial $F_{1}$ adenosine triphosphatase $\beta$-subunit. J. Clin. Invest. 86:220-227.

7. Wolkoff, A. W., A. C. Samuelson, K. L. Johansen, R. Nakata, D. M. Withers, and A. Sosiak. 1987. Influence of $\mathrm{Cl}^{-}$on organic anion transport in short-term cultured rat hepatocytes and isolated perfused rat liver. J. Clin. Invest. 79:1259-1268

8. Hagenbuch, B., B. Stieger, M. Foguet, H. Lübbert, and P. J. Meier. 1991. Functional expression cloning and characterization of the hepatocyte $\mathrm{Na}^{+} /$bile acid cotransport system. Proc. Natl. Acad. Sci. USA. In press.

9. Kurisu, A., P. Nilprabhassorn, and A. W. Wolkoff. 1989. Preparation of ${ }^{35}$ S-sulfobromophthalein of high specific activity. Anal. Biochem. 179:72-74.

10. Colman, A. 1984. Translation of eukaryotic messenger RNA in Xenopus oocytes. In Transcription and Translation. A Practical Approach. B. D. Hames and S. J. Higgins, editors. IRL Press Limited, Oxford. 271-302.

11. Hagenbuch, B., H. Lübbert, B. Stieger, and P. J. Meier. 1990. Expression of the hepatocyte $\mathrm{Na}^{+} /$bile acid cotransporter in Xenopus laevis oocytes. J. Biol. Chem. 265:5357-5360.

12. Maniatis, T., E. F. Fritsch, and J. Sambrook. 1982. Molecular Cloning: A Laboratory Manual. Cold Spring Harbor Laboratory, Cold Spring Harbor, NY. $461 \mathrm{pp}$.

13. Stremmel, W., and P. D. Berk. 1986. Hepatocellular uptake of sulfobromophthalein and bilirubin is selectively inhibited by an antibody to the liver plasma membrane sulfobromophthalein/bilirubin binding protein. J. Clin. In vest. 78:822-826.

14. Schwenk, M., R. Burr, L. Schwarz, and E. Pfaff. 1976. Uptake of bromosulfophthalein by isolated liver cells. Eur. J. Biochem. 64:189-197.

15. Laperche, Y., A. M. Preaux, and P. Berthelot. 1981. Two systems are involved in the sulfobromophthalein uptake by rat liver cells: one is shared with bile salts. Biochem. Pharmacol. 30:1333-1336.

16. Stremmel, W., and H. E. Diede. 1990. Cellular uptake of conjugated bilirubin and sulfobromophthalein (BSP) by the human hepatoma cell line Hep G2 is mediated by a membrane BSP/bilirubin binding protein. J. Hepatol. (Amst.). 10:99-104.

17. Scharschmidt, B. F., J. G. Waggoner, and P. D. Berk. 1975. Hepatic organic anion uptake in the rat. J. Clin. Invest. 56:1280-1292.

18. Sorrentino, D., B. J. Potter, and P. D. Berk. 1990. From albumin to the cytoplasm: the hepatic uptake of organic anions. Prog. Liver Dis. 9:203-224.

19. Delage, Y., S. Erlinger, M. Duval, and J. P. Benhamon. 1975. Influence of dehydrocholate and taurocholate on bromosulphthalein uptake, storage, and excretion in the dog. Gut. 16:105-108.

20. Anwer, M. S., and D. Hegner. 1978. Effect of $\mathrm{Na}^{+}$on bile acid uptake by isolated rat hepatocytes. Hoppe-Seyler's Z. Physiol. Chem. 359:181-192.

21. Caflisch, C., B. Zimmerli, J. Reichen, and P. J. Meier. 1990. Cholate uptake in basolateral rat liver plasma membrane vesicles and in liposomes. Biochim. Biophys. Acta. 1021:70-76.

22. Frimmer, M., and K. Ziegler. 1988. The transport of bile acids in liver cells. Biochim. Biophys. Acta. 947:75-99. 